\title{
Anna Stocka
}

Białystok

\section{Echa obchodów setnej rocznicy podpisania przez USA Deklaracji Niepodległości w prasie warszawskiej}

Każdego roku, 4 lipca Amerykanie świętują kolejne rocznice podpisania w Filadelfii Deklaracji Niepodległości. Tradycyjnie na ten dzień przygotowywane są federalne i prywatne imprezy. Święto to nie może odbyć się bez parad, koncertów, pokazów sztucznych ogni oraz bicia dzwonów. Rodziny w ten dzień organizują tradycyjne barbecue lub pikniki. Charakterystyczne jest też przyozdabianie budynków w flagi i barwy narodowe. W 1876 r. przypadała „okrąła”, setna rocznica uzyskania niepodległości, dlatego Amerykanie postanowili uczcić to wydarzenie w sposób szczególny. Główne uroczystości - jak zawsze - zorganizowano 4 lipca, niemniej jednak przez cały rok odbywały się imprezy towarzyszące.

W poniższym artykule opisałam wrażenia korespondentów prasy warszawskiej $^{1}$ z przebiegu uroczystości zorganizowanych w 1876 roku. W tym celu wykorzystałam relacje zamieszczane na łamach polskich dzienników i periodyków w latach 1873-1877. W pracy tej postaram się odpowiedzieć na pytania: czy prasa

1 Czyli dzienników i periodyków ukazujących się w ówczesnej Warszawie. W stolicy Królestwa Polskiego ukazywało się wówczas 5 dzienników, które literatura podzieliła na „gazety” i „kurierki”. „Gazety” uchodziły za poważne pisma o charakterze polityczno-informacyjnym. Ten nurt reprezentowały: „Gazeta Polska” (dalej „GP”), „Gazeta Warszawska” (dalej „GW”) i „Gazeta Handlowa” (,GH”). Natomiast „kurierki” zaliczano do pism brukowych. Do tej grupy należały: „Kurier Warszawski” (dalej „KW”) i „Kurier Codzienny” (dalej „KC”). Oprócz dzienników wydawano kilkadziesiąt periodyków: tygodników, dwutygodników i miesięczników. Wraz ze wzrostem liczby tytułów czasopism nastąpił proces ich specjalizacji. Obok periodyków społeczno-polityczno-kulturalnych, kierowanych do szerszego grona czytelników, powstawały czasopisma przeznaczone dla określonego odbiorcy, np.: kobiet, młodzieży, rodzin, kleru czy Żydów. Warto też dodać, że zasięg oddziaływania gazet i czasopism wydawanych w ówczesnej Warszawske nie ograniczał się jedynie do tego miasta, bowiem prasa stołeczna docierała też do innych miejscowości położonych w zaborze rosyjskim, mieli też do niej dostęp czytelnicy mieszkający w pozostałych dwóch zaborach. Więcej o prasie warszawskiej tego okresu można przeczytać: Prasa polska w latach 1864-1918, pod red. J. Łojka, Warszawa 1976; Z. Kmiecik, Zarys historii prasy polskiej w Królestwie Polskim: w latach 1864-1904, Warszawa 1972; Z. Kmieciak: Prasa polska w okresie pozytywizmu: (1864-1885), Warszawa 1971; W. Giełżyński, Prasa warszawska: 1661-1914, Warszawa 1962. 
warszawska interesowała się amerykańską rocznicą, na jakie atrakcje zwracano szczególną uwagę i w jakim stopniu Polacy zaangażowali się w obchody?

By godnie uczcić setną rocznicę podpisania Deklaracji Niepodległości, Amerykanie zaplanowali na 1876 rok szereg imprez. Rozmach niektórych przedsięwzięć sprawił, że zaczęto przygotowywać je kilka lat wcześniej, dlatego pierwsze artykuły na ten temat pojawiły się już w 1873 roku. „Gazeta Warszawska” w jednym z artykułów wyjaśniła, dlaczego tak wielkie znaczenie dla Amerykanów miały obchody jubileuszu: jednq $z$ najbardziej interesujacych epok $w$ historyi Ameryki przedstawiaja obecnie Stany Zjednoczone. Przygotowuja się one obchodzić swoje zwycięstwa wielka uroczystościa $w$ d. 4 lipca 1876 r., t.j. w stuletniq rocznice „Deklaracyi”, która stata się wiara polityki narodu amerykańskiego. Rok teraźniejszy i przyszły pełne sa pamiątek historycznych, które obchodzq się $i$ obchodzić się będq solennie. Amerykanie sq bardzo dumni ze swojej niepodległości, ze swojej pozycji w świecie, ze swojej pomyślności wewnętrznej, ze swojej historyi ${ }^{2}$.

Na miejsce centralnych uroczystości wybrano Filadelfię, mimo iż o ten zaszczyt ubiegały się inne, duże miasta Stanów Zjednoczonych: Boston, który się uważa za środkowy punkt cywilizayi ${ }^{3}$, Chicago, które poczytuje się za jedyne miasto $w$ świecie i New York, co znów czuje się jako realna stolica wielkiej Rzeczypospolitej $^{4}$. Oprócz powyższych ośrodków do rywalizacji o ten przywilej przystąpiło St. Luis i Cincinnati. Korespondent „Kuriera Codziennego” - T. F. Krajewski, w jednej ze swoich korespondencji, słusznie zauważył, że w przypadku większości krajów europejskich wybór miejsca byłby oczywisty, np. Francja wskazałaby Paryż, Wielka Brytania - Londyn, a Austria - Wiedeń. Natomiast stolica USA nie była aż tak dominującym ośrodkiem, jak wymienione wcześniej stolice europejskie ${ }^{5}$. Niemniej jednak w wyborze przeważyły względy historyczne. Jednakże mimo oczywistych motywów kierujących rządem amerykańskim, niektóre metropolie $\mathrm{z}$ trudem pogodziły się z tą decyzją. Zwłaszcza, że organizacja tego typu imprezy dawała duże możliwości rozwoju miasta i regionu. Warszawskie gazety i periodyki były zgodne, że rząd amerykański podjął słuszną decyzję, wybierając Filadelfię na miejsce centralnych uroczystości, ponieważ, jak słusznie zauważono, było to jedyne miejsce, które zaakceptowały inne miasta bez niepotrzebnych komentarzy ${ }^{6}$.

\footnotetext{
2 J. D., Korespondencja Gazety Warszawskiej, New York, d. 20 sierpnia 1875 r., „GW” 17 IX 1875 , nr 204, s. 3.

3 W cytatach zachowano oryginalną pisownię.

4 „GW” 31 III 1874, nr 70, s. 3.

5 [T. F. Krajewski], Listy z Ameryki, New York, 24 kwietnia 1876, „KC” 11 V 1876, nr 104, s. $1-2$.

6 Ibidem; J. Delikowski, Z Ameryki, „Wiek” 7 VI 1876, nr 124, s. 2; Wystawa Powszechna w Filadelfi, „GH” 10 VI 1876, nr 127, s. 1.
} 
Największą atrakcją obchodów było zorganizowanie w Filadelfii „International Exhibition Arts, Manufactures and Products of the Soil and Mine". To przedsięwzięcie, z uwagi na swój międzynarodowy charakter, budziło poza Ameryką największe zainteresowanie. Warto zwrócić uwagę, że pomysł urządzenia wystawy międzynarodowej nie był nadzwyczaj oryginalny. Można nawet powiedzieć, że w ówczesnym świecie panowała swoista moda na tego rodzaju imprezy. Tę w Filadelfii uznaje się za szóstą po Londynie (1851 i 1862 r.), Paryżu (1855 i 1867 r.) i Wiedniu (1873 r.), chociaż zarówno przed, jak i pomiędzy nimi odbywały się inne także światowej klasy wystawy, ale nie miały one aż takiego zasięgu? ${ }^{7}$ Popularności wystaw, na których prezentowano osiągnięcia państw w różnych dziedzinach bez wątpienia sprzyjał dynamiczny rozwój różnych gałęzi przemysłu. Organizowano je nie tylko po to, by móc zaprezentować swoje dokonania. Miały one też swój praktyczny wymiar, bowiem ułatwiały nawiązywanie międzynarodowych kontaktów handlowych. Producenci mieli też niepowtarzalną okazję do porównania swoich wyrobów z produktami podobnej klasy wytwarzanymi przez inne kraje.

Motywy wyboru niniejszej formy obchodów trafnie wyjaśnił Władysław Olendzki na łamach dwutygodnika „Niwa”: Wystawa w Filadelfii różnić się będzie od dotychczasowych nie tylko niezmiernym obszarem, mnogościq i bogactwem przedmiotów, ale też $i$ charakterem - wystawa $w$ Filadelfii będzie uroczystościq narodowa. Najpracowitszy z narodów ziemi, popisem owoców pracy postanowit uczcić stuletniq rocznice swojej niepodlegtości $i^{8}$. Stany Zjednoczone poprzez zorganizowanie wystawy międzynarodowej niewątpliwie planowały osiągnąć kilka celów, z jednej strony był to dobry sposób, by godnie i efektownie uczcić jubileusz Dnia Niepodległości, a z drugiej strony, jak wyżej wspomniano, wystawy organizowano w celu nawiązania ogólnoświatowych kontaktów handlowych. Amerykanie tym sposobem mogli rozreklamować swoje wyroby na całym świecie. Nie należy też zapominać, że była to świetna okazja, by pochwalić się przed międzynarodową widownią tym, co udało się osiągnąć Stanom Zjednoczonym w czasie stu lat swojego istnienia. Była to również skuteczna metoda, by zaangażować $\mathrm{w}$ obchody jubileuszu państwa $\mathrm{z}$ całego świata, gdyż raczej trudno sobie wyobrazić, że kraje chociażby europejskie z własnej inicjatywy przybyłyby, by świętować zwycięstwo republikańskiej rewolucji. Zwłaszcza, że niektóre z nich same borykały się z ruchem niepodległościowym, który rozwijał się wśród narodów zamieszkujących ich terytoria, podobnie jak sto lat wcześniej Wielka Brytania. Wprawdzie w obchodach Dnia Niepodległości nie wzięły udziału głowy najważniejszych mocarstw, ale przynajmniej udało się przycią-

\footnotetext{
7 http://libwww.library.phila.gov; B. Giberti, Designing the Centennial: a history of the 1876 International Exhibition in Philadelphia, Lexington 2002, s. 33-74.

8 W. M. Olendzki, Wystawa powszechna w Filadelfi, „Niwa” 1875, nr 13-24, t. 8, s. 990.
} 
gnąć do Filadelfii wystawców, a co ważniejsze rzesze korespondentów, którzy relacjonowali przebieg obchodów.

Na kilka lat przed „okrągłą” rocznicą podpisania Deklaracji Niepodległości w prasie warszawskiej pojawiły się pierwsze artykuły na temat tej rocznicy. Opisywano w nich m.in. postępy w budowie miasteczka wystawowego, nastawienie innych państw, jak i rodaków do jubileuszu. Spekulowano też nad tym, czy Amerykanie zdążą ze wszystkim na czas i czy w ogóle doprowadzą swoje przedsięwzięcia do końca 9 .

Polskie gazety i czasopisma początkowo dziwiły się, że Amerykanie wybrali wystawę powszechną na główną atrakcję Dnia Niepodległości. Wiele osób, zarówno w Polsce, jak i w Ameryce było zdania, że przyniesie ona jedynie straty finansowe, podobnie jak to miało miejsce w przypadku wystawy wiedeńskiej z 1873 roku. „Biesiada Literacka” twierdziła, że nie odniesie ona sukcesu, ponieważ popularność wystaw już przeminęła, gdyż organizowano je zbyt często ${ }^{10}$. Organizatorzy zapewniali wprawdzie, że postarają się ustrzec błędów swoich poprzedników, mimo to ciągle nie brakowało głosów sceptycznych.

Stany Zjednoczone nie mogły być też pewne, czy inne państwa, do których wystosowano oficjalne zaproszenia nie odrzucą ich. „Gazeta Warszawska” w 1874 roku podawała, że: rozesłane wezwania do udziału przyjmuja dotąd bardzo obojętnie i jedynie Niemcy, Hollandya i Anglia urzędownie udział zapewnity ${ }^{11}$. Obawy, nie tylko dziennikarzy, ale i samych organizatorów były niewątpliwie uzasadnione, bowiem wystawę zorganizowano de facto w celu uczczenia rewolucji republikańskiej, występującej przeciwko monarchii angielskiej. Stąd wynikała obawa, że zbojkotują ją kraje o niedemokratycznych systemach politycznych. Wielką niewiadomą pozostawał przede wszystkim udział Wielkiej Brytanii.

W podobnym tonie wypowiadał się na łamach „Bluszczu” Jan Karłowicz - pochodzący z litewskiej rodziny szlacheckiej etnograf, językoznawca i muzyk $^{12}$. Zwrócił on uwagę, że: Wieść o mającej nastapić wystawie filadelfijskiej, przed niedawnym jeszcze czasem wzbudziła tylko watpliwość. Zdawało się, że po kłopotach finansowych, w które Austryę wprowadziła wystawa z r. 1873 nie prędko inny naród odważy się na rzecz tak ryzykowna. Spodziewano się, ze wystawa $w$ Filadelfii zamrze $w$ swoim zarodku, lub suchotniczy wieśdź będzie

\footnotetext{
9 Zapowiedzi wystawy pojawiły się m.in.: Projektowana na $1876 r$. wystawa powszechna w Filadelfii, „TI” 1874, nr 324, s. 174; „GW” 17 XII 1875, nr 279, s. 3; J. D., Korespondencja Gazety..., s. 3; Wiadomości Bieżące Zagraniczne, „GW” 23 IV 1874, nr 88, s. 2; Wystawa międzynarodowa w Filadelfii w roku 1876, „GH” 9 VIII 1875, nr 148, s. 3.

10 Wystawa w Filadelfii, „Biesiada Literacka” 25 II 1876, nr 8, s. 121.

11 Wiadomości Bieżące Zagraniczne, „GW” 23 IV 1874, nr 88, s. 2.

12 O. Gajkowa, S. Urbańczyk, Karłowicz Jan Aleksander Ludwik, PSB, t. 12, Wrocław 1966-1967, s. 53-57.
} 
$\dot{z} y w o t, z$ powodu nie przyjęcia udziału przez rzady zagraniczne. Każdy miał na myśli humbugi i rozmaite figle amerykańskie $i$ spodziewat się, że Europa nie zoodzi się na rzecz tak ryzykowna z obawy strat $i$ kompromitacyi. Lecz wszystkie przewidywania nie sprawdziły się. Stowo stało się ciałem. Wystawa w Filadelfii odbędzie się, $i$ to nie o własnej sile Amerykanów, lecz przy szczerej a skutecznej pomocy państw nie tylko europejskich, ale i azyatyckich, oraz afrykańskich ${ }^{13}$. Polskich korespondentów zdumiewało to, iż mimo wielu trudności, Stany Zjednoczone doprowadziły swój zamysł do końca. Dużym sukcesem Amerykanów było przyciągniecie wystawców z różnych stron świata. A z drugiej strony należy zauważyć, że państwa ze wszystkich kontynentów przyjęły zaproszenia, mimo iż z pewnością słyszały wiele sceptycznych głosów, niewierzących w powodzenie całego przedsięwzięcia. Trzeba przy tym zwrócić uwagę na oddalenie Stanów Zjednoczonych i wynikające $\mathrm{z}$ tego powodu utrudnienia, a nawet ograniczenia w przewożeniu eksponatów oraz związane z tym koszty. Ten fakt mógł z całą pewnością zniechęcać do wysyłania towarów za ocean.

Zaproszenie do wzięcia udziału w wystawie w Filadelfii przyjęła także Rosja. Rozporządzenie o utworzeniu oddziału ruskiego na tej imprezie podpisane przez ministra finansów 9 października 1875 r. można było przeczytać $\mathrm{m}$ im. w „Gazecie Handlowej”. Zgodnie z zarządzeniem władz polscy wystawcy z zaboru rosyjskiego, którzy chcieli wysłać swoje towary do Filadelfii musieli postępować zgodnie z procedurą ustaloną przez władze carskie. Ustawa nakazywała wszystkim chętnym wysłanie na własny koszt wybranych produktów do St. Petersburga, bowiem w mieście tym powołano specjalną komisję, która zajmowała się organizacją oddziału. Wspomniana komisja zgodnie z regulaminem miała obowiązek przejrzeć wszystkie nadesłane eksponaty i odrzucić te, które uznałaby za „niedogodne”. Każdy chętny musiał wypełnić deklarację i wysłać ją do 15 grudnia 1875 roku. Ostateczny termin nadsyłania płodów wyznaczono na 15 lutego 1876 roku $^{14}$. Tak późny termin może tłumaczyć, dlaczego Rosjanom nie udało się przygotować na czas swojego sektora na wystawie. Drugim, o wiele istotniejszym powodem była awaria statku wiozącego ich eksponaty do Filadelfii.

Wystawę powszechną oficjalnie otworzono 10 maja 1876 roku, w ten sposób uczczono rocznicę powierzenia dowództwa nad Armią Kontynentalną George'owi Washingtonowi (10 V 1775 r.), a zamknięto dokładnie po sześciu miesiącach, miało to symbolizować sześć lat walki o niepodległość15.

W ceremonii otwarcia wystawy powszechnej oprócz przedstawicieli władz amerykańskich wzięli udział goście z zagranicy, wśród których - jak podaje Sy-

13 J. Karłowicz, Wystawa powszechna w Filadelfii, „Bluszcz” 17 V 1876, nr 20, s. 158.

14 (Dz. War.), Postanowienie o ruskim oddziale wystawy międzynarodowej 1876 r. w Filadelfii, „GH” 11 XI 1875, nr 250, s. 1, „GH” 12 XI 1875, nr 251, s. 1, „GH” 13 XI 1875, nr 252, s. 1.

15 www.phmc.state.pa.us 
gurd Wiśniowski - największy entuzjazm zgromadzonego tłumu wywołał cesarz brazylijski Don Pedro II. Z pewnością dlatego, iż był on jedynym władcą obcego państwa, która przybył na tą uroczystość. Inne państwa reprezentowały osoby zajmujące niższe pozycje w państwie, najczęściej byli to przedstawiciele ambasad. Poza tym polski korespondent odnotował, że w ceremonii, mimo ulewnego deszczu, uczestniczyło około 300 tys. ludzi ${ }^{16}$.

Wiśniowski zauważył również, że inaugurację zorganizowano zgodnie z tradycją amerykańską. Widoczną różnicą był brak książąt oraz wojskowych prezentujących swoje mundury z orderami. Uwagę polskich korespondentów zwróciły też skromne stroje, w porównaniu z europejskimi zwyczajami, amerykańskich dostojników ${ }^{17}$.

Prezydenta amerykańskiego Wiśniowski scharakteryzował w ten sposób: Grant wygladat jak zamożny episier, podtatusiaty Don Pedro, jak zubożały szlachcic polski, wybierający się na audyencya do sędziego, przed którym toczy się proces odwieczny o szczq̨tki jego fortuny ${ }^{18}$. Wiśniowski nie ukrywał swojej niechęci do amerykańskiego prezydenta. Wielokrotnie pisał o nim obraźliwe komentarze. Ale to nie znaczy, że Ulysses Grant nie zasłużył na krytykę, wprost przeciwnie, gdyż w latach swojej prezydentury roztrwonił zdobytą w czasie wojny sławę. Toteż negatywne opinie na jego temat wyrażane przez polskiego korespondenta odzwierciedlały również nastroje panujące wśród społeczeństwa amerykańskiego, a nie tylko jego prywatne odczucia.

Dalej Wiśniowski relacjonował: Ciekawym dla cudzoziemców objawieniem, byt zapat, z jakim lud witat popularnego brazylijskiego monarchę, znakomitych własnych męzów, Szermana i innych wodzów, podczas gdy prezydenta ani jeden oklask, ani słowo przyjazne nie ucieszyło ${ }^{19}$. Nie było to do końca prawdą, ponieważ inni polscy korespondenci, którzy również byli na tej samej uroczystości wspominali, że prezydent otrzymał owacje. Może nie były one zbyt en-

16 Liczba widzów podana przez Wiśniowskiego była znacznie przesadzona. Amerykanie podają, że wzięło w niej udział około 100 tys. osób, z czego za bilet wstępu zapłaciło ok. 76 tys.: www.phmc.state.pa.us; F. Fischer, The Centennial Exhibition, the Philadelphia Museum of Art, and Hector Tyndale, „Magazine Antiques” 2002. O 76 tys. widzów pisała też w „GH” (Wystawa w Filadelfii, „GH” 13 VI 1876, nr 129, s. 2), wyjaśniając przy tej okazji, że pierwsze liczby, które pojawiły się w prasie amerykańskiej były znacznie przesadzone. Korespondent dziennika rozczarował się też liczbą zwiedzających wystawę w pierwszych dniach, obawiał się, że jednak poniesie ona fiasko finansowe.

17 S. Wiśnowski, Z wystawy, „Kłosy” 1 VI 1876, nr 570, s. 349; L. S., Z Filadelfii, „Biesiada Literacka" 14 VII 1876, nr 28, s. 439.

18 S. Wiśnowski, $Z$ wystawy..., s. 349. O tym samym wydarzeniu pisał Wiśniowski również w „TI”. Więcej na ten temat można przeczytać w artykule: A. Stocka, Stany Zjednoczone po wojnie secesyjnej w świetle „Tygodnika Ilustrowanego”, w: Anglosasi, Francuzi i Polacy - wzajemny wizerunek dawniej i dziś, pod red. P. Guzowskiego i M. Kameckiej, Białystok 2005, s. 158-161.

19 S. Wiśnowski, Z wystawy..., s. 350. 
tuzjastyczne, ale dowodziły, że Wiśniowski w niektórych sytuacjach mijał się $\mathrm{z}$ prawdą ${ }^{20}$.

Natomiast korespondent „Gazety Handlowej” narzekał na niewłaściwe zachowanie publiczności zgromadzonej na inauguracji. Wspominano, że ich brak obycia ujawnił się szczególnie w momencie, gdy w czasie uroczystości zaczął padać ulewny deszcz. Okazało się - pisano w warszawskim tygodniku - jak mało Amerykanie przestrzegaja form towarzyskich, a raczej, że wcale delikatności w obejściu nie znaja. Każdy myśli tylko o sobie, o swojem najdroższem „ja”, nie troszczqc się wcale o swojego squsiada, którego uważaja za największa przeszkode $i$ brzemię $i$ wcale nie zwracaja na to uwagi, że innym ludziom wolno zyć i pragnać wygody. Brutalny egoizm Amerykanów wystąił tu $w$ całej nagości $i$ wcale niekorzystne wrazenie $w$ cudzoziemcach wywoła ${ }^{21}$. Autorowi chodziło $\mathrm{z}$ pewnością o niezbyt delikatne szukanie schronienia przed deszczem w wagonach kolejowych.

W czasie inauguracji przemawiało wiele osobistości. Na niektóre mowy korespondenci prasy warszawskiej zwrócili większą uwagę. Wiśniowskiego przykuła wypowiedz biskupa metodystów. Pisał o niej w ten sposób: Przez kwadrans mówit Panu Bogu o jego zaletach, chetpit się narodowa mąrościa Amerykanów, modlit za Granta i t.p., aż znudzona publiczność poczęta wołać „cut it short" (kończ!) Umilkt wreszcie, ku ogólnej radości. Niemądry ten purytsński pacierz, zamieniony w kazanie, zupetnie odpowiadaja tutejszemu zwyczajowi, by wszędzie i zawsze wprowadzać pobożność udana ${ }^{22}$. Natomiast w „Tygodniku Ilustrowanym" Wiśniowski na temat powyższej przemowy pisał: Po marszu jakiś staruszek modlit się, niestety, zbyt rozwlekle $i$ w wyrazach nieokazujacych wiele smaku. Była to jedna z owych długich, nudnych, napuszonych purytańskich odezw do nieba, które raczej kazaniem niż modlitwa nazwać wypada ${ }^{23}$. Ten przykład obrazuje, że Wiśniowski na łamach obu czasopism wypowiadał się w podobnym tonie. Przeszkadzać mogło jedynie to, że autor powtarzał te same informacje, nie siląc się na oryginalność.

Innym przemówieniom Wiśniowski nie poświęcił aż tak wiele miejsca, pominął nawet mowę samego prezydenta. W „Tygodniku Ilustrowanym” stwierdził, jedynie, że najlepszym ustępem tej mowy było zapewne jej zakończenie, otwierające lakonicznie wystawę ${ }^{24}$. Swoją niechęć do prezydenta USA Wiśniowski manifestował niejednokrotnie, potwierdzają ją nie tylko jego uszczypliwe komentarze, których nie szczędził w czasie opisywania ceremonii otwarcia wystawy,

20 Wystawa Powszechna w Filadelfii, „GH” 10 VI 1876, nr 127, s. 1; [T. F. Krajewski], Listy z Ameryki: otwarcie wystawy: Filadelfia 11 maja 1876, „KC” 29 V 1876, nr 117, s. 1-2.

21 Wystawa Powszechna..., „GH” 13 VI 1876, nr 129, s. 1.

22 S. Wiśnowski, $Z$ wystawy..., s. 349.

23 S. Wiśniowski, Listy z wystawy filadelfijskiej, „TI” 10 VI 1876, nr 24, s. 376.

24 Ibidem. 
ale także wiele innych artykułów, które pisał w tym czasie do różnych gazet i czasopism. Zgoła odmienne zdanie na temat mowy Granta miał Jordan Delikowski, korespondent dziennika „Wiek”. Był on pod jej wrażeniem, ponieważ nie zawierała elementów politycznych. Całe przemówienie Granta przytoczyła „Gazeta Polska”25, „Wiek”26 i „Kurier Codzienny”27.

Prezydent w swoim przemówieniu podziękował wszystkim uczestnikom za przyjęcie zaproszenia do udziału w uroczystości. Następnie wygłosił kilka słów o samej wystawie. W jego opinii głównym jej celem było zaprezentowanie osiągnięć narodu amerykańskiego, wypracowanych w ciągu stuletniego istnienia i przyrównanie swego dorobku z dokonaniami innych państw. Przy czym zdawał on sobie sprawę, że w niektórych dziedzinach Stany Zjednoczone nie mogły skutecznie rywalizować ze starszymi narodami, ale mimo to był dumny $\mathrm{z}$ tego, co udało się im osiągnąć w tak krótkim czasie ${ }^{28}$.

Organizatorzy zadbali również o specjalną oprawę muzyczną uroczystości otwarcia wystawy międzynarodowej. Orkiestra zagrała m.in. specjalnie skomponowany na tą okazję przez Wilhelma Richarda Wagnera marsz, za napisanie, którego zapłacono kompozytorowi rzekomo 5 tys. dolarów. Korespondent „Biesiady Literackiej” podpisujący się inicjałami L. S. ironizował, że Wagner pisząc ten utwór: myślat, że Amerykanie mają uszy tak jak pancerniki z dubeltowej blachy, bo tyle w marszu trąb i bębnów nasadzit, ze go styszeli chyba nawet ci co przed stu laty odeszli z tej ziemi ${ }^{29}$. Ponadto uwagę korespondenta „Biesiady Literackiej” przykuł występ chóru, który zaprezentował publiczności historię USA poczynając od przybycia pierwszych kolonistów na kontynent amerykański na żaglowcu „Mayflower”30.

Kulminacyjną częścią ceremonii było oficjalne otwarcie wystawy. Dokonał tego prezydent uruchamiając silnik parowy Georga H. Corlissa, który miał wprawiać $\mathrm{w}$ ruch wszystkie urządzenia znajdujące się w miasteczku wystawowym. Moment ten był jednym z największych atrakcji dla zgromadzonej wokół publiczności ${ }^{31}$. Po czym: Tysiąc bander wystrzelito ku niebu z każdej wieży, kazdego stupka parku. Sto armat ryknęło, dzwony niezliczone uderzyly w takt $i$ nutę Händlowskiego Alleluja! - trzykroć stotysięcy gardzieli w parku, a stotysięcy widów stojących za jego obrębem, powitało głośnym hura flagę narodową. Drzewa

25 (Times), Dziat polityczny: Stany..., „GP” 30 V 1876, nr 118, s. 1.

26 J. Delikowski, Z Ameryki, „Wiek” 10 VI 1876, nr 127, s. 2.

27 [T. F. Krajewski], Listy z Ameryki: otwarcie wystawy: Filadelfia, 11 maja 1876, „KC” 29 V 1876 , nr 117 , s. $1-2$.

28 J. Delikowski, Z Ameryki, „Wiek” 10 VI 1876, nr 127, s. 2.

29 L. S., Z Filadelfii, „Biesiada Literacka” 14 VII 1876, nr 28, s. 439.

30 J. Delikowski, Z Ameryki, „Wiek” 10 VI 1876, nr 127, s. 2.

31 Wystawa w Filadelfii, „GH” 13 VI 1876, nr 129, s. 1-2. 
tamały się, dachy transeptów jęczały pod tłumami, pnoncemi się na nie, by ogarnqć jednym rzutem wspaniała scenę. Zaiste, wiele rzeczy dziwnych widziałem, lecz nawet we śnie nie przeczułem równie poważnego, rzewnego, świetnego widowiska, jak pól miliona patriotów ${ }^{32}$.

Polscy korespondenci narzekali, że jeszcze przez kilka tygodni po otwarciu można było znaleźć wiele niedociągnięć. Krytykowano wystawców, ponieważ nie zdążyli przewieść na czas eksponatów i opieszale urządzali swoje sektory. „Gazeta Handlowa” ironizowała, że pośpiech widoczny był jedynie na kilka dni przed otwarciem, a po tym jak ono nastąpiło tempo urządzania znacznie spadło ${ }^{33}$. T. F. Kajewski zauważył, że najszybciej uporządkowano Main Building ${ }^{34}$. Z całą pewnością przygotowanie ekspozycji utrudniało oddalenie Stanów Zjednoczonych. Niewątpliwie zebranie i przewiezienie przez ocean wszystkich przedmiotów nie należało do prostych przedsięwzięć. O wiele łatwiejsze pod tym względem zadanie mieli gospodarze, którzy dzięki temu mogli zaprezentować się bardziej okazale. Nie można zapominać, że część winy za niedociągnięcia spadała też na organizatorów, którzy nie zdążyli na czas z wszystkimi pracami i zbyt późno udostępnili wystawcom gmachy.

Wystawę urządzono na obrzeżach Filadelfii w Fairmount Park na obszarze 285 akrów. Była pierwszą, w której nie umieszczono eksponatów tylko w jednym budynku. W sumie na całym obszarze zbudowano około 250 gmachów. Do najważniejszych zaliczyć można: Main Exhibition Building, Machinery Hall, Agricultural Hall, Horicultural Hall, Memorial Hall i Art Annex. Oprócz powyższych osobne gmachy posiadało 11 spośród 37 biorących udział w wystawie państw. Poza tym własne pawilony urządziła część stanów i terytoriów Unii. Swoimi gmachami nie dysponowały jedynie słabiej zaludnione i mniej zagospodarowane stany bądź terytoria amerykańskiego Zachodu ${ }^{35}$. Natomiast, jak wspominał Jan Karłowicz, z zupełnie innego powodu w wystawie nie wzięły udziału stany południowe, takie jak: Alabama, Georgia, Floryda, Luizjana, obie Karoliny, gdyż one świadomie zbojkotowały obchody. W ten sposób chciały zademonstrować swój sprzeciw wobec polityki rządu centralnego względem amerykańskiego Południa ${ }^{36}$. Celem stanów południowych było też okazanie niezadowolenia $\mathrm{z}$ istnienia Unii i zwrócenie uwagi na to, że pozostają w związku wbrew własnej woli.

\footnotetext{
32 S. Wiśnowski, Z wystawy..., „Kłosy” 1 VI 1876, nr 570, s. 350

33 Wystawa w Filadelfii, „GH” 13 VI 1876, nr 129, s. 2.

34 [T. F. Krajewski], Listy z Ameryki...: dnia 5 maja 1876, „KC” 24 V 1876, nr 114, s. 1-3; T. [F. Krajewski], Listy z Ameryki...: 27 maja 1876, „KC” 14 VI 1876, nr 130, s. 1-3; S. Wiśniowski, Wystawa filadelfijska, „Tygodnik Ilustrowany”, nr 16, 15 IV 1876, s. 252; S. Wiśniowski, Wystawa..., nr 24, 10 VI 1876, s. 376.

35 http://libwww.library.phila.gov.

36 J. Karłowicz, Szkice z wystawy filadelfijskiej 1876 r., „Biblioteka Warszawska” 1877, t. 1, s. 27.
} 
Feliks Fryze zauważył, że większość budynków w Fairmount Park miała charakter czasowy, na pamiątkę miał pozostać jedynie Memorial Hall i Horicultural Hall ${ }^{37}$. Oprócz gmachów wystawowych w miasteczku wybudowano restauracje i budynki administracyjne. Wielką atrakcją dla zwiedzających były też fontanny. Korespondent „Kuriera Codziennego” zwrócił szczególną uwagę na tzw. katolicką fontannę, na której umieszczono wizerunki amerykańskich bohaterów narodowych, w tym Tadeusza Kościuszki i Kazimierza Pułaskiego ${ }^{38}$.

Wystawę zwiedziło blisko $10 \mathrm{mln}$ ludzi. Była to liczba o wiele wyższa aniżeli na innych tego typu imprezach, które odbywały się do tamtej pory. Warto zauważyć, że populacja Stanów Zjednoczonych wynosiła wówczas $46 \mathrm{mln}$. Najwięcej osób zwiedziło wystawę w sierpniu i we wrześniu, o tym świadczyły wpływy ze sprzedaży biletów ${ }^{39}$. Jeszcze w czerwcu 1876 roku Wiśniowskiego niepokoiła niska frekwencja, obawiał się, że organizatorzy poniosą straty podobnie, jak to miało miejsce kilka lat wcześniej w Wiedniu ${ }^{40}$. Mniejsze zainteresowanie wystawą w pierwszych miesiącach po otwarciu T. F. Krajewski tłumaczył upałami, które skutecznie zniechęcały do przyjazdu do Filadelfii ${ }^{41}$.

Można przypuścić, że wpływy byłyby wyższe, gdyby zdecydowano się na otwarcie wystawy również $\mathrm{w}$ niedzielę. O zamknięciu jej w tym dniu zadecydował bardzo silny żywioł purytański ${ }^{42}$. Bawienie się $w$ pobożnisiów - pisał Wiśniowski - jest tu moda. Ono wywołało ukaz, by wystawę zamykać w niedziele, pozbawiajac tłumy robocze jedynej sposobności ogladania jej bez straty czasu, dyrekcya zaś wystawy znacznego dochodu ${ }^{43}$. W podobnym tonie wypowiadał się na łamach „Wieku” Jordan Delikowski. Podkreślał on, że zamykanie w niedzielę miasteczka wystawowego było dużym uniedogodnieniem, bowiem tym sposobem klasa robotnicza nie miała możliwości zwiedzić jej w dniu wolnym od pracy ${ }^{44}$. Niemniej jednak trudno teraz jednoznacznie stwierdzić, jak wielkie straty ponieśli z tego powodu organizatorzy.

Korespondenci prasy warszawskiej niejednokrotnie zachęcali Polaków do przyjazdu i obejrzenia wystawy. Podawali wiele cennych, praktycznych informacji, dzięki którym przybywający mogli sprawniej poruszać się po Stanach Zjednoczonych i Filadelfii. Tym sposobem wszyscy, którzy zdecydowali się na

\footnotetext{
37 F. Fryze, Z Ameryki.., ,KW” 30 VIII 1876, nr 191, s. 1-2.

38 [T. F. Krajewski], Listy z Ameryki...: dnia 5 maja 1876, „KC” 24 V 1876, nr 114, s. 3.

39 http:/libwww.library.phila.gov.

40 S. Wiśnowski, Z wystawy, „Kłosy” 1 VI 1876, nr 570, s. 349.

41 T. F. Krajewski, Listy z Ameryki...: New York, 1 października 1876, „KC” 21 X 1876, nr 233, s. 1.

42 Korrespondencye Gazety polskiej, z wystawy Amerykańskiej, przez Sygurda Wiśniowskiego, Filadelfia, 25 maja, 1876 roku, „GP” 14 VI 1876, nr 130, s. 2.

43 S. Wiśnowski, Z wystawy..., „Kłosy” 1 VI 1876, nr 570, s. 349.

44 J. Delikowski, Z Ameryki, „Wiek” 12 VI 1876, nr 128, s. 2.
} 
podróż, mogli ustrzec się wielu pułapek czyhających na nich w tym kraju, a związanych głównie z nieznajomością amerykańskich realiów ${ }^{45}$.

Wiele użytecznych informacji zamieściła „Gazeta Warszawska” w cyklu artykułów pt. Z wystawy w Filadelfii: kilka uwag dla udających się na Wystawę Powszechnq ${ }^{46}$. Autor bardzo skrupulatnie opisał w niej swoją podróż najpierw koleją przez Europę, a później statkiem za Atlantyk. Podawał przy tym szczegóły dotyczące formalności, jakie powinni dopełnić wybierający się, na poszczególnych etapach podróży. Radził też jak uniknąć pułapek, jakie zastawili na podróżnych agenci pośredniczący w organizacji tego typu wypraw ${ }^{47}$.

Polscy korespondenci oceniali wystawę filadelfijską bardzo wysoko, chociaż zauważyli, że Amerykanie nie ustrzegli się pewnych potknięć. Wiśniowski uważał, że organizatorzy powinni staranniej dobierać eksponaty, ponieważ obok cennych przedmiotów było bardzo wiele bezwartościowych. Dużo zastrzeżeń miał on też do budynków znajdujących się w miasteczku wystawowym. Stwierdził, że lepiej wyglądały one na rycinach aniżeli $\mathrm{w}$ rzeczywistości ${ }^{48}$. Podobne odczucia mieli inni polscy korespondenci. Oni też przyznawali, że wygląd budynków wystawowych nie wywarł na nich większego wrażenia. Bardziej przypadły im do gustu gmachy, jakie przygotowywali Europejczycy w czasie wystaw organizowanych w Wiedniu, Paryżu, czy Londynie ${ }^{49}$.

T. F. Krajewski spostrzegł, że wystawa w Filadelfii była ogromną promocją Stanów Zjednoczonych. Pokazała, że kraj ten w wielu dziedzinach górował nad resztą świata. Korespondent „Kuriera Codziennego” nie miał wątpliwości, że dzięki niej Amerykanie zwiększą eksport swoich towarów ${ }^{50}$.

Główne uroczystości stulecia niepodległości Stanów Zjednoczonych odbyły się 4 lipca 1876 w Filadelfii. Najszerzej zrelacjonował je na łamach kobiecego tygodnika ilustrowanego „Bluszcz”, Jan Karłowicz. Zanim opisał on, jakie atrakcje przygotowali Amerykanie, by uczcić to wydarzenie rzetelnie przybliżył czytelnikom okoliczności przyjęcia i podpisania Deklaracji przez 56 tzw. „Ojców Założycieli Ojczyzny Amerykańskiej” oraz rolę Filadelfii w tym historycznym zdarzeniu. Niestety pominął późniejsze, równie ważne wydarzenia, czyli wojnę z Anglią o utrzymanie postanowień Kongresu Kontynentalnego. W artykule tym zabrakło też wątków poruszających polski wkład w amerykańską rewolucję, ale to ze względu na surową cenzurę nie powinno nikogo dziwić. Może zdumiewać

45 S. Wiśniowski, Z wystawy..., „Kłosy” 8 VI 1876, nr 571, s. 365-366.

46 Z wystawy do Filadelfii: kilka uwag dla udających się na Wystawę Powszechna, „GW” 6-30 III 1876 , nr 52-70.

47 Ibidem.

48 S. Wiśnowski, $Z$ wystawy..., „Kłosy” 1 VI 1876, nr 570, s. 349.

49 Ak, Z Filadelfii, „Biesiada Literacka” 2 V 1876, nr 19, s. 295-298; L. S., Z Filadelfii, „Biesiada Literacka” 14 VII 1876, nr 28, s. 439.

50 Ibiden. 
jedynie fakt, że cenzura nie wyeliminowała z tekstów poświęconych amerykańskiej rocznicy słowa niepodległość i informacji, w jaki sposób Amerykanie ją wywalczyli ${ }^{51}$.

Karłowicz porównywał Deklarację Niepodległości z francuską Deklaracją Praw Człowieka i Obywatela. Niemniej jednak uznał, że treść tej pierwszej wyprzedzała i przewyższała orzeczenie ogłoszone w czasie rewolucji francuskiej. Autor dopatrywał się również innych podobieństw w historii obu państw (porównanie wojny secesyjnej z wojną prusko-francuskią oraz powrót Francji do rządów republikańskich, zaś Stanów Zjednoczonych do zasad głoszonych w Deklaracji, chodzi tu o równość wszystkich ludzi, łącznie z Czarnymi mieszkańcami, a także chęć przywrócenia uczciwości w rządzie) ${ }^{52}$. Ze względu na panującą w zaborze rosyjskim cenzurę Karłownicz nie miał możliwości porównania historii Polski z historią USA, chociaż mógł znaleźć wiele elementów wspólnych (walka o niepodległość, uchwalenie pierwszych na świecie konstytucji). Chociaż wydaje się, że podanie za przykład Francji mogło nasuwać również skojarzenia z Polską.

Po takim wstępie Karłowicz przeszedł do opisywania uroczystości zorganizowanych 4 lipca. Jego uwagę zwróciły liczne parady, które zorganizowano w tym dniu, jak i w dniach poprzedzających. Największe wrażenie wywarła na nim wielka parada, która przeszła głównymi ulicami Filadelfii wieczorem 3 lipca. Polski korespondent spostrzegł, że wzięło w niej udział wiele osobistości z całego świata, wśród których nie zabrakło przedstawicieli władz Stanów Zjednoczonych, w tym dwóch kandydatów do fotela prezydenta oraz gości z zagranicy z cesarzem brazylijskim i księciem szwedzkim Oskarem na czele. Pochód zamykali członkowie różnych kościołów, bractw i stowarzyszeń, a także reprezentanci firm i fabryk. Karłowicz dodawał, że idącym towarzyszyły wystrzały z broni, salwy armatnie i fajerwerki ${ }^{53}$. Feliks Fryze, korespondent „Kuriera Warszawskiego”, wyjaśniał, że Amerykanie bardzo lubili organizować parady i pokazy sztucznych ogni podczas uroczystości państwowych, stąd nie dziwi tak duża ich liczba w czasie obchodów Dnia Niepodległości. Warto dodać, że parady zorganizowane w celu uczczenia 4 lipca zrobiły na Feliksie Fryzie duże wrażenie ${ }^{54}$.

Karłowicz był pod dużym wrażeniem nie tylko samego pochodu, ale zachowania osób biorących w nim udział, jak i ludności, która obserwowała to wydarzenie: Nigdzie nie widziałem tak zwanego u nas "ludu” vulgo „motłochu”, $i$ w ogóle fakt ten najwięcej uderza przybysza $z$ Europy: każdy tu jest nie tylko porzqdnie ubranym, ale i mine ma człowieka porzadnego, a co jeszcze ważniejsze, zachowuje się jak człowiek przyzwoity. Przekleństwo, głośne lub grubiańskie

\footnotetext{
51 J. Karłowicz, Listy z zamorza, „Bluszcz” 2 VIII 1876, nr 31, s. 245.

52 Ibidem.

53 Ibidem; Jubileusz amerykański, „GH” 25 VII 1876, nr 163, s. 3.

54 F. Fryze, Z Ameryki..., „KW” 28 VII 1876, nr 166, s. 1-2.
} 
słowo, tak jest tu rzadkiem, jak u nas w Europie częstem. Dość powiedzieć, że podczas obecnych obchodów stuletnich, nawet $w$ nocy, stato na ulicach petno kobiet z małemi dziećmi i mnóstwo kilkuletnich wyrostków bez rodziców i opiekunów, nikt ani myślat o chowaniu zegarków lub chustek do nosa w najgłębsze tajniki ubrania, a pomimo to gazety tutejsze, co wiedzq o kazddym niezwyktym wydarzeniu $i$ wypadeczku, nie donoszq wcale o kradzieżach kieszonkowych ${ }^{55}$. Warto zwrócić uwagę, że również mieszkańcy USA, a nie tylko władze państwowe, byli zaangażowani w obchody. Świadczył o tym ich czynny udział w federalnych uroczystościach. Sami też organizowali prywatne imprezy: barbecue lub pikniki. Ponadto Amerykanie przystrajali domy flagami i innymi ozdobami w barwach narodowych. Korespondent „Kuriera Codziennego” - T. F. Krajewski, zauważył, że w tym okresie było bardzo trudno kupić flagę ${ }^{56}$.

Federalne uroczystości Dnia Niepodległości odbyły się w Filadelfii przed Gmachem Niepodległości (Independence Hall). Karłowicz spostrzegł, że na trybunie, którą zbudowano przed tym budynkiem, zasiedli z jednej strony: prezydent, gubernatorowie różnych stanów, członkowie Kongresu oraz przedstawiciele innych państw, a z drugiej strony około 3 tys. osób, którym udało się zdobyć bilet. Karłowicz nie omieszkał dodać, że pomiędzy estradą dla muzyków a trybuną zgromadził się tłum do tego stopnia ciekawskich ludzi, że wdrapali się na rosnące wokół drzewa, by stamtąd móc obserwować całą uroczystośćs7.

Zgodnie z tradycją, głównym punktem Dnia Niepodległości zarówno przed gmachem Independence Hall, jak i we wszystkich innych zakątkach Stanów Zjednoczonych, było odczytanie Deklaracji Niepodległości. Wszędzie uczyniono to o tej samej porze. W Filadelfii zaszczytu tego dostąpił prawnuk Richarda Henry'ego Lee, notabene noszący to samo imię i nazwisko. W tym celu prezydent Stanów Zjednoczonych Ulysses Grant wręczył mówcy oryginalny, oprawiony w ramę dokument Deklaracji Niepodległości. „Bluszcz” w tym miejscu przytoczył fragment tego aktu: Gdy w biegu wypadków naród zmuszony jest rozerwać zwiazki polityczne, które go tączyly z innym, zajać wśród mocarstw świata odrębne $i$ równe innym stanowisko, do którego upoważniaja go prawa natury $i$ boskie, to szacunek należny mniemaniu ludzkości nakazuje mu ogłosić powody, sktaniajace go do oderwania się. Uważamy prawdy następne za oczywiste: że wszyscy ludzie stworzeni sq równymi, że obdarzeni sa przez Stwórce pewnemi nietykalnemi prawami, a szczególnie prawem do życia, wolności i szukania szczęścia, że dla zabezpieczenia praw tych zaprowadzane sq rzqdy, czerpiace swa stuszna władze w przyzwoleniu rzadzacych, że kiedykolwiek jaki rzqd daży

\footnotetext{
55 J. Karłowicz, Listy z zamorza, „Bluszcz” 2 VIII 1876, nr 31, s. 245-246.

56 T. F. Krajewski, Listy z Ameryki: o wystawie w Filadelfii: New York, 27 lipca 1876, „KC” 7 VIII 1876 , nr 173 , s. 1.

57 F. Fryze, Z Ameryki..., „KW” 28 VII 1876, nr 166, s. 1-2.
} 
do obalenia tych ustaw, to naród ma prawo zmienić go lub usuną́ $i$ ustanowić nowy, opierając go na takich zasadach $i$ władze jego $w$ taki sposób urządzając, jaki mu się zda najstosowniejszym do zapewnienia bezpieczeństwa i pomyślno$s c i^{58}$. Można uznać zacytowany fragment, jak i całą Deklarację Niepodległości za dokument uniwersalny, z którym mogły utożsamiać się inne narody. Warto podkreślić, że przytoczony urywek nie daje do zrozumienia, że dotyczy w ogóle Stanów Zjednoczonych, wprost przeciwnie przedstawiono taką część, w której słowa ujęte były w ten sposób, że każde społeczeństwo mogło się z nimi identyfikować, a w szczególności Polacy. Zaskakujące jest, że cenzura dopuściła, by w polskim tygodniku z tamtego okresu znalazł się cytat mówiący, że każdy naród ma prawo do suwerenności, wynikającej z praw naturalnych i boskich, a każdy człowiek do życia, wolności, równości i szczęścia, zaś rząd powoływano w celu zabezpieczenia przestrzegania tych zasad i zastrzegano możliwość zmiany władzy, gdyby rządzący nie wywiązywali się ze swoich obowiązków.

Wieczorem, na jednym ze wzgórz Fairmout Parku odbył się pokaz sztucznych ogni. Karłowicz podawał, że miał on być niezwykle widowiskowy, ale gwałtowna burza pokrzyżowała szyki organizatorom. Stąd zaplanowane na dwie godziny widowisko trwało zaledwie pół godziny ${ }^{59}$. „Gazeta Polska” dodawała, że podobne imprezy odbyły się we wszystkich większych i mniejszych miastach Stanów Zjednoczonych. Przy tej sposobności korespondenci prasy warszawskiej dostrzegli, że obchody w całym kraju miały podobny schemat ${ }^{60}$. Spostrzeżenie to potwierdził przebywający wówczas w San Francisco Julian Horain, pochodzący z Wileńszczyzny literat. Nie podjął on trudu szczegółowo opisania imprez mających miejsce tego dnia w tym mieście tłumacząc, że: to co się odbywato w San Francisco, miało miejsce we wszystkich innych miastach Stanów Zjednoczonych, $w$ mniejszych lub większych rozmiarach ${ }^{61}$. Dostrzegł, że wyjątkiem były Stany Południowe, które albo zbojkotowały uroczystości, albo obchodziły je bardzo skromnie.

O tym, jak Amerykanie i nie tylko ci, którzy mieszkają w San Francisco obchodzili „okrągły” jubileusz, Julian Horain pisał w ten sposób: Amerykanie - najmłodsi z narodów cywilizowanych, urzqdzaja swoje obchody pamiatkowe $z$ wielka ostentacya, teatralnie, i trzeba wyznać prawdę, trochę po dziecinnemu. Cały tydzień poprzedzajacy 4 lipca był tak huczny, hałaśliwy, strzelniczy i działobitny, że doprawdy byliśmy radzi, jak się te fety skończyty; chociaż jeszcze przez tydzień szumiało w uszach. Wyobraźcie sobie, że w San Francisco, mieście mającym tyleż prawie ludności co Warszawa, kilka tysięcy dzieci, obojej ptci, mniej

\footnotetext{
58 J. Karłowicz, Listy z zamorza, „Bluszcz” 2 VIII 1876, nr 31, s. 245-246.

59 Ibidem.

60 „Gazeta Polska” 26 VII 1876, nr 164, s. 3.

61 „Gazeta Polska” 31 VIII 1876, nr 192, s. 2.
} 
więcej dziesięcioletnich, po całych dniach i nocach latało po mieście z pukawkami, petardami, racami, fajerwerkami, strzelało w prawo i lewo, puszczało race, rzucało pod nogi przechodniom petardy, na podwórzach drewnianych domów zapalano fajerwerki... $i$ że wszystko skończyło się na kilku zaledwie kalectwach, że się miasto nasze, po większej części drewniane, nie spalito, to potrzeba przypisać nie roztropności dzieci, nie czujności policyi, ale chyba Opatrzności $i^{62}$. Horain zwrócił uwagę na poważne konsekwencje nierozważnego korzystania z sztucznych ogni, petard, a także broni. To był problem, z którym borykały się całe Stany Zjednoczone, a nie tylko San Francisco.

Horain przy tej okazji zauważył, że również część mieszkających w USA Polaków czynnie uczestniczyła w Dniu Niepodległości. Ich udział był widoczny w czasie parad, gdzie wraz z innymi narodami maszerowali po ulicach miast. Szczególnie okazale zaprezentowała się według niego kompania ułanów, która podobno przedefilowała w miejscowości Northeim (stan Wisconsin) przed obliczem miejscowego proboszcza ${ }^{63}$.

W Warszawie z okazji stulecia niepodległości USA wydano dwa tomy, tłumaczonej z francuskiego, „Historyi Stanów Zjednoczonych” autorstwa Edouarda Laboulaye' ${ }^{64}$. W kolejnych latach pojawiły się dwa kolejne tomy tegoż wydawnictwa. Tom drugi w całości poświęcony był rewolucji amerykańskiej65. Co ciekawe w jednym ze znajdujących się na końcu książki dopełnień opisano dwie podróże Tadeusza Kościuszki do Ameryki. Autor nie podał zbyt wielu szczegółów, ponieważ twierdził, że nie dotarł do wiarygodnych źródeł i biografii polskiego bohatera. Narzekał, że nie ukazało się dotychczas żadne opracowanie omawiające losy Polaka za oceanem i jego wkład w rewolucję amerykańską. Zdumiewać może, że nie usunięto fragmentu o Kościuszce z książki E. Laboulaye'a. Być może cenzura przepuściła ten rozdział z uwagi, iż był on autorstwa konserwatywnego francuskiego historyka i nie zawierał zbyt wielu kontrowersyjnych informacji.

Na łamach prasy warszawskiej o Kościuszce i Pułaskim pisała jedynie „Biblioteka Warszawska" ${ }^{66}$. W jednym z artykułów Ernest Swieżawski opisał tablicę pamiątkową wydaną w USA przez Juliana Horaina z okazji 100-lecia dziejów Stanów Zjednoczonych. Autor podawał, że Horain umieścił na niej podobizny

\footnotetext{
62 Ibidem.

63 Ibidem.

64 E. Laboulaye de Lefebvre, Historya Stanów Zjednoczonych, t. 1-2, Warszawa 1876.

65 M. M. Drozdowski, Z dziejów stosunków polsko-amerykańskich: 1776-1944, Warszawa 1982, s. $70-71$.
}

66 Miesięcznik o charakterze naukowym kierowany przez konserwatystów i trafiający przede w ręce ziemiaństwa, czyli do warstw, które zaborca uważał za najbardziej podatne na hasła niepodległościowe. Jego oddziaływanie nie było wielkie, ponieważ jego nakład liczył w 1875 r. jedynie 800 egzemplarzy. 
Kościuszki i Puławskiego obok wizerunków innych bohaterów amerykańskich. Warto zauważyć, że autor tego artykułu czynił dość śmiałe aluzje do ich udziału w polskim ruchu niepodległościowym. Dobrze więc pan Horain zrobit - pisze Ernest Swieżawski - łaczac, jakoby symbole, portrety członków trzech wypadków kończacych dzieje XVIII wieku, nad Potomakiem, Wista i Sekwanq ${ }^{67}$. Atoli ze względu na udziat naszych ziomków w dziejach poczatkowych Unii, to większy jest on ze strony Kazimierza Pułaskiego, jak Kościuszki. Pułaski, może najznaczniejszy uczestnik konfederacji barskiej, grat znakomitsza w Ameryce od Tadeusza rolę ${ }^{68}$. Dalej Swieżawski wymienił zasługi Puławskiego w walce o niepodległość USA i wspomniał o wystawieniu mu pomnika w Sawannah w 1855 roku. Przytoczył też fragmenty dwóch wierszy napisanych na cześć Kościuszki i Puławskiego, wychwalające ich działalność na kontynencie amerykańskim ${ }^{69}$. Niemniej jednak zdumiewa fakt, że cenzura nie zakwestionowała niektórych fragmentów recenzji, bowiem autor dość wyraźnie nawiązywał w nich do polskich powstań końca XVIII wieku.

Warto nadmienić, że 1876 rok w Stanach Zjednoczonych upłynął nie tylko pod znakiem obchodów stulecia. Rok ten obfitował w wiele ważnych wydarzeń, które w dużym stopniu wpłynęły na amerykańską rocznicę. Trzeba też podkreślić, że również niektóre wypadki odcisnęły piętno na obchodach. Szczególna zależność widoczna była między jubileuszem a wyborami prezydenckimi, które odbyły się jesienią tegoż roku. Jak zauważył Sygurd Wiśniowski na łamach „Tygodnika Ilustrowanego": Zdaje się że przypomnienie świętej rocznicy, tak wspaniale obchodzonej $w$ tym roku, wptywa $i$ na politykę. We wszystkich warstwach budzi się żadza odnowienia $i$ uszlachetnienia społeczeństwa. Naród ocknąt się $i$ uczut spodlenie, wywotane nienasycona żadzq łatwych bogactw, wyrazajace się dobitnie w sferach rzadzacych, gdzie ani poczucie godności osobistej, ani pamięć poprzedniej sławy nie odstraszaja ludzi wysoko stojacych od wyrzeczenia się czci dla zysku. Wszyscy czuja poniżenie, wyptywajace dla narodu ze skandalów waszyngtońskich. (...) Oprócz tędy stuletnicy, oprócz wystawy, gość europejski ujrzy tu $w$ roku 1876 odrodzenie się narodu do cnót ojców. Będzie to walka uczciwego ludu przeciw zepsutym do gruntu demagogom ${ }^{70}$. W istocie Amerykanie byli zmęczeni polityką rządu centralnego, skandalami, które co chwila wstrząsały opinią publiczną oraz wszechobecną korupcją, na każdym szczeblu władzy, a szczególnie na najwyższych stanowiskach państwowych, w otoczeniu samego prezydenta. Grant kończył swoją kadencję skompromitowany, a społeczeństwo

\footnotetext{
67 Chodzi tu o uczestnika rewolucji francuskiej markiza Marie Josepha de La Fayette'a.

68 E. Swieżawski, Piśmiennictwo krajowe i zagraniczne, „Biblioteka Warszawska” 1875, t. 4, s. 139 .

69 Ibidem, s. 138-140.

70 S. Wiśniowski, Listy z wystawy Filadelfijskiej, „TI” 22 IV 1876, nr 22, s. 267.
} 
domagało się zmian, odnowy, powrotu do korzeni i haseł głoszonych w Deklaracji Niepodległości.

O ile obchody jubileuszu wywarły wpływ na wybory prezydenckie, o tyle na samej uroczystości odcisnęła piętno klęska Georga A. Custera pod Little Bighorn, o której gazety amerykańskie zawiadomiły 5 lipca. Wiadomość ta przyczyniła się do skrócenia obchodów ${ }^{71}$. O wojnie amerykańsko-indiańskiej, a szczególnie o klęsce Custera w bitwie pod Little Bighorn warszawskie gazety i periodyki pisały bardzo starannie. Informowano też o tym, jak wielkie wrażenie na Amerykanach zrobiła śmierć gen. Custera i jego ludzi, gdyż ten młody, charyzmatyczny dowódca cieszył się wyjątkowym poważaniem w społeczeństwie amerykańskim. Nierzadko pojawiały się opinie, że śmierć Custera była o wiele większym szokiem dla Amerykanów, aniżeli zabójstwo Abrahama Lincolna.

Polskie gazety i periodyki chętnie podejmowały temat amerykańskiej okrągłej rocznicy wywalczenia niepodległości. O dużym zainteresowaniu uroczystościami zorganizowanymi w 1876 roku świadczy liczba artykułów zamieszczonych w prasie warszawskiej. Redakcje polskich gazet i periodyków nie zlekceważyły tego wydarzenia i wysłały własnych korespondentów, którzy przesyłali im bezpośrednie relacje. Najwięcej o jubileuszu pisał Sygurd Wiśniowski. Warto odnotować, że swoimi wrażeniami z jubileuszu dzielił się z czytelnikami kilku pism: „Gazety Polskiej”, „Tygodnia Ilustrowanego”, „Kłosów” i „Tygodnika Mód i Powieści”. Podobnie jak Jan Karłowicz, który pisał do „Bluszczu” i „Biblioteki Warszawskiej".

Z uwagi na swój międzynarodowy charakter, najwięcej uwagi polscy korespondenci poświęcili wystawie powszechnej zorganizowanej w Filadelfii specjalnie w celu uczczenia Dnia Niepodległości. Była ona dla korespondentów jednym z najbardziej fascynujących wydarzeń w ówczesnym świecie. Potwierdzają to liczne, obszerne korespondencje zamieszczane na łamach warszawskich gazet i czasopism. Opisywały one bardzo precyzyjnie cały obszar, na którym zorganizowano wystawę oraz eksponaty, jakie zgromadzono w poszczególnych gmachach. Odwiedzający wystawę korespondenci prasy warszawskiej starali się też odnaleźć i ocenić rzeczy, przysłane przez Polaków.

\section{The centenary of the signing of the Declaration of Independence - echoes in the Warsaw press}

Each year on July 4 Americans celebrate subsequent anniversaries of the signing of the Declaration of Independence. On that day numerous federal and private events take place. In 1876 Americans decided to celebrate the centenary

\footnotetext{
71 Ibidem.
} 
of gaining independence in a special way - with the main feast on July 4 and minor events throughout the whole year.

The complexity of some festivities required starting extensive preparations even a few years earlier. The biggest attraction of the celebrations was the International Exhibition of Arts, Manufactures and Products of Soil and Mine organized in Philadelphia. This undertaking, due to its international character, caused the greatest interest abroad.

This article focuses on reports describing celebrations of the centenary in the Warsaw press in the years 1873-1877. The first articles appeared in 1873, when the president officially declared that the exhibition would be the focal point of the celebrations. From that time on the Polish press tried to follow subsequent stages in the preparations for the exhibition. The author of this article describes the impressions of Polish correspondents observing the festivities of 1876 and the contribution of Poles in the celebrations.

Numerous articles on the centenary printed in Polish newspapers and periodicals reflected a great interest in the topic. Editors sent their correspondents to the United States in order to have immediate and direct relations. Sygurd Wiśniowski was the one who wrote the greatest number of reports. He shared his impressions with "Gazeta Polska", "Tygodnik Ilustrowany", "Kłosy" oraz "Tygodnik Mód i Powieści". Jan Karłowicz wrote for "Bluszcz" and "Biblioteka Warszawska".

It is worth mentioning that Polish correspondents focused on the exhibition in Philadelphia because of its international character. Polish correspondents perceived it as one of the most extraordinary events of those days. Such a conclusion may be drawn on the basis of numerous extensive articles in the Warsaw press. Their authors were fascinated by the magnitude of the exhibition. They also admired Americans for their efficiency in organizing such a worldwide known event. 